\title{
Role of Social Media Brand Communication on Online Brand Experience and Brand Equity Dimensions: Applying to the Higher Education Sector ${ }^{1}$
}

\author{
Dr. Heba Hassan Sadek
}

Lecturer of Marketing, College of Management and Technology

Arab Academy for Science, Technology\& Maritime Transport

hebahassan@aast.edu

\begin{abstract}
The growing competition that exists among universities particularly private and international universities in the higher education (HE) sector has led them to focus on building their brand equity to have a unique position. Thus, this study emphasis on the role of social media brand communication, as one of the most important elements in building brand equity, which consists of firm-generated content (FGC) and user-generated content $(U G C)$ to examine their impact on building brand equity dimensions via online brand experience in the Egyptian HE sector. Questionnaires were distributed electronically to gather data. Data gathered from 399 undergraduate students from private and international universities. Data have been analyzed via Structural Equation Modelling (SEM), AMOS 22. Results indicated that UGC has a significant positive direct impact on online brand experience more than FGC. Additionally, it has been indicated that online brand experience played a mediator role between UGC and brand equity dimensions. This study contributes to the branding literature by highlighting the vital elements in building brand equity in the $H E$ sector that needs more attention. Also, this study helps the service providers in the HE institutions to focus on the significance role of UGC in developing online brand experience, which helps to build brand equity dimensions.
\end{abstract}

Keywords: Social media, online brand experience, brand equity dimensions, higher education sector

${ }^{1}$ Received in 13 April 2021, accepted in 22 June 2021. 


\section{1- Introduction}

Nowadays, university brand equity becomes a vital issue due to the highly competitive environment caused by globalization and digital transformation (Alam \& Saeed, 2016; Yu et al., 2016; Khorshtaria et al., 2020). The increased competition between HE institutions alongside the fast changing digital marketplace have made it essential for HE sector to become more marketing oriented (Mourad et al., 2011). Therefore, the HE institutions need to focus more on treating students as customers while developing strong university brand equity (Lomer et al., 2018; Mourad et al., 2019). Especially, the choice of HE institution is considered as long-term personal investment that determines the student's career life and success. Thus, the role of brand equity is crucial due to its pivotal impact as it acts as a risk relief (Mourad et al., 2011).

One of the most effective tool in building high brand equity is social media brand communication(Stojanovic et al.,2018).Social media as a marketing communication tool has a great power on the student's decision in selecting which HE institution to choose, and in building high brand equity (Muhmurti \& Selvanayagam, 2019). Particular, students aged 18 and over are known like digital natives as stated by Prensky (2001). They depend deeply on social media brand communication to share and investigate for pertinent news towards HE institutions (Messner, 2020). As a result, social media brand communication is regarded as the most effective sources of information that influence student-HE relationships (Le et al., 2019). Social media brand communication is categorized based on content-generation of firms and users that generates brand information, and intensifies the chat of views and experiences around education services, which may impact brand equity (Stojanovic et al., 2018). Thus, Berry (2000); Brakus et al. (2009) and Beig and Khan (2018) affirmed that effective social media brand communication can create a positive online brand experience, which is one of the most important brand constructs that is conceptualized as a customer response, which will lead to better brand equity (MorganThomas \& Veloutsou, 2013). 


\section{2- Research Problem}

Despite the significance of social media brand communication and online customer experience in building service brand equity. There is a huge need to focus on the social media brand communication role in developing high brand equity via the creation of online experience towards the brand as mentioned by Beig and Khan (2018) and Dwivedi et al. (2020). This is because previously some researchers have studied the relationship between traditional marketing communication tools and brand experience. While, customers today are using social media for searching for information about brands (Bambauser-Sachse \& Mangold, 2011; Dwivedi et al., 2020). Thus, online brand experience can happen by exposure to marketing communication and advertising through the use of social media (Brakus et al., 2009).

Moreover, research on brand equity and its determinants in HE institutions is scare and needs more focus due to the rising importance of HE branding (Mourad et al., 2019). Additionally, few studies have differentiated among the two types of social media brand communication including FGC that is controllable via the firm and UGC that is uncontrollable communication tool on brand equity development. Therefore, this study intends to fulfill these gaps by examining the role of social media brand communication including FGC and UGC on building brand equity via online brand experience particularly in the HE sector in Egypt in one model. The following sections of the paper offer an overview of the theoretical background regarding the relevant topics in the literature. Following, the methodology used to obtain students' responses is presented, proceeding with the discussion of the findings, the implications for research and for practice, the conclusion, the research limitations and further directions and, finally the research recommendations.

\section{2-Theoretical Background and Hypotheses Development}

\section{2-1 Branding in HE Institutions}

Branding in the service sector is considered more critical than branding in the manufacturing sector because of the distinctive features of the service sector (De Chernatony \& Dall Olmo Riley, 1999). One of the vital 
service sectors in any economy is the HE sector which like any other service in providing intangible, heterogeneous, perishable and inseparable services, resulting in significant risks associated with its use (Heckman \& Montalto, 2016). Besides, the HE sector is more complex than other services due to the fact that university degree is the only purchase that can build a successful career of student that make it a hard decision (Muhmurti \&Selvanayagam, 2019). So to overwhelmed this challenge, previous studies have proposed solutions by focusing on tangible clues to services (Leong et al., 2018). Nevertheless, these solutions reduce physical intangibility more than intellectual and psychological intangibility of HE services (Wirtz \&Lovelock, 2016). So in the look for the best solution, Mourad et al. (2019) stated that the greatest way to reduce the apparent risks associated with intellectual and psychological intangibility is to build brand equity effectively.

Brand equity is considered a very crucial concept for both academics and practitioners because marketers can achieve a sustainable competitive advantage via building successful brands (Lasser et al., 1995). Brand equity is described as the value added that a particular brand gives to a product (Farquhar, 1989). It can be examined based on three main standpoints; financially based brand equity, employee based brand equity and customer based brand equity (CBBE). Keller (1993) mentioned that according to the marketing viewpoint, brand equity is indicated as CBBE. Based on the previous studies, CBBE has many classifications and it is seen as a multidimensional construct such as Aaker (1991) who defined CBBE as a set of brand assets and liabilities associated with a brand, its name, and symbol that augment to or detract from the value provided by a product or service for a company and/or its customers. Keller (1993) who stated that CBBE is the differential impact of brand knowledge on consumer response to brand marketing. Lasser et al. (1995) who focused on 5 CBBE dimensions that consists of social image, performance, attachment, value and trustworthiness, which is the center of this research.

Nevertheless, the significance of CBBE, there is a paucity of empirical research that focuses on the role of CBBE in the service sector especially in the HE sector (Menictas et al., 2012; Mourad et al., 2011). Brand equity is regarded as a key influence on the HE customer's decision as it serves 
as a risk reduction and differentiation tool especially in today's severe competition (Mourad et al., 2019). In Egypt, HE demand is rising and the industry is considerably changing, with new International Branch Campuses (IBCs), National Non-Profit Universities "Ahleya”, and private providers joining the public-funded universities. These new universities have led to a severe competition not only among the private and IBCs universities but also between the National Non-Profit and Public universities (Mourad et al., 2011; "Egypt's education system is by far the largest in the region - Brussels Research Group", 2021). Based on the HE ministry report (2020), the market in Egypt comprised mainly 27 public universities and 33 private, Ahleya and international universities. Therefore, Egypt offers an interesting area for research on CBBE in HE due to the challenging competitive marketing environment (Mourad et al., 2011).

Consequently, the Egyptian HE industry has changed its focus to marketing oriented approaches, like advertising, and branding to help universities compete domestically and internationally (Mourad et al., 2019). Therefore, this research will focus on the role of social media, which is the most recent marketing communication tool, in building brand equity from student's perspective since students are the core customers that have different needs and expectations (Perera et al., 2020). Besides, brand equity can be built via different brand constructs like brand experience, which is one of the most crucial brand constructs that are influenced by some key factors such as marketing communication tools. However, previous studies such as Iglesias et al. (2017); Beig and Khan (2018) and Dwivedi et al. (2020) argued that more studies are needed to examine how social media brand communication will create a memorable online brand experience, which may lead to develop a brand equity. Therefore, this research will fill this gap by focusing on social media brand communication, online brand experience and CBBE dimensions in the Egyptian HE sector from student's perspective.

\section{2-2 Social Media Brand Communication and Online Brand Experience}

Social media has become vital for the marketing communications mix 
(Kaplan \& Haenlein, 2010). It is used to generate brand communications and online brand experiences (Tuten \& Mintu-Wimsatt, 2018). You can define social media as a portable and web-based Technology that creates a highly collaborative, cooperative and communal platform that enables people and businesses to communicate, connect, interact, share information and make decisions (Kietzmann et al., 2011). Social media users practice social media in many ways, including social networking and professional networking (Beig \& Khan, 2018). Additionally, social media can provide marketers with an effective way to promote business and interact with customers (Filo et al., 2015).

In 2020 , about 3.6 billion individuals worldwide were active social media users. It is expected that the number of users will grow to 4.41 billion in 2025 which will constitute $56.7 \%$ of the world's population ("Number of Social Media Users in the World | Statista", 2020). Especially, Facebook is the greatest used social media platform in the world and is considered the largest virtual country in the world (Jacobson et al., 2020). The number of active Facebook users is 2.7 billion/ month, and it is said that this number will gradually increase in most countries in 2020 (“Facebook: Active Users Around the World | Statista", 2020). In Egypt, active Facebook users represent the highest percentage of other platforms at 80.15\% (Social Media Statistics Egypt | StatCounter Global Statistics, 2020). It was not surprising that marketers make up decisions based on social media, given the huge audience using Facebook, which helps companies to achieve their marketing strategies and goals. (Alalwan et al., 2017; Jacobson et al., 2020). Facebook's brand pages are an effectual platform for brand communication in a social media context (Tafesse, 2015).

Two forms of social media brand communication have appeared, facilitating the exchange of information between consumers and businesses, and between consumers themselves (Kudeshia \& Kumar, 2017). These types are FGC and UGC, which help to shape online experience (Nisar et al., 2020). In more details, FGC indicates the information that arises from a firm including product / service representation, promotional advertisements, company information, etc. On the other side, UGC refers to incoming ratings, opinions, and recommendations from other users who are independent of firm 
management (Nisar et al., 2020). So, organizations created branded content that allows brands to communicate with customers on social media particularly Facebook pages (Ashley \& Tuten, 2014). Besides, those pages permit limitless number of followers every day to engage and post relevant messages (Lipsman et al., 2012), which have led the users to depend on other users' reviews and comments before taking their decisions whether or not to buy a product/service (Duan et al., 2008).

Particularly, institutions in the HE sector recently depend deeply on social media brand communication to be connected with students (Perera et al., 2020). Based on the previous studies such as Godey et al. (2016) and Beig and Khan (2018), social media brand communication has the power to provide a favorable customer experience for a brand, especially Facebook brand pages that can provide an online brand experience to create a satisfactory customer response. In more details, Godey et al. (2016) emphasized that digital content plays crucial role in developing and enhancing the overall online brand experience. Additionally, Beig and Khan (2018) indicated that the content accessible on Facebook whether FGC or UGC help to build favorable, enjoyable, and pleasant customers' experience towards the brand. Moreover, Dwivedi et al. (2020) argued that insufficient studies have examined the impact of social media on online brand experience. Therefore, this study will focus on the impact of social media brand communication taking into account two types, FGC and UGC on building online brand experience. Thus, the researcher hypothesized the following hypotheses based on the different types of social media brand communication:

H1: FGC has a positive impact on online brand experience.

H2: UGC has a positive impact on online brand experience.

\section{2-3 Online Brand Experience and Brand Equity Dimensions}

Online brand experience is the newest source of sustainable differentiation and is a new field of competition, since it helps marketing managers in developing brand equity (Beig \& Nika, 2019). This is due to the changing consumer preference from the functional features to excellent experiences thanks to the evolution of integrated 
communication and information technologies that promote a new approach in marketing (Beig \& Nika, 2019). Based on Zarantonello and Schmitt (2010), consumers need marketing communications that inspire their minds, to create a pleasant experience. According to Iglesias et al. (2017), brands must provide an enjoyable experience so that their customers can differentiate them particularly in service sector because of the distinctive characteristics of services, to be able to build high brand equity.

Nearly $59 \%$ of the 1,000 marketing managers surveyed in a recent study about brand experience said that brand experience is a way to build lasting relationships with their customers. More than a third thought they would book $21-50 \%$ of their marketing budget for the brand experience over the coming 5 years (Andreini et al., 2018). Previous studies such as Ekinci and Hosany (2006); Brakus et al. (2009) and Ramanathan et al. (2012) showed that brand experience is an important element of marketing and brand communication management. Jung and Soo (2012) asserted that brand experience is the basis for creating a strong brand. In addition, Shamin and Mohsin (2013); Chen et al. (2016) and Iglesias et al. (2017) confirmed that experience impacts the development of brand equity.

As mentioned early, this study is based on the brand equity from a marketing perspective, including CBBE dimensions, but there was little agreement regarding the brand equity dimensions particularly in HE institutions (Mourad et al., 2019). Thus, this study will focus on 5 CBBE dimensions based on the prior studies such as Perera et al. (2020), Mourad et al. (2019) and Lasser et al. (1995) namely: social image, performance, attachment, value and trustworthiness. First, social image referred to the consumer's opinion of the prestige in which the consumer's social group embraces towards the brand. Second, performance is seen as the entirety of the physical job, which is expressed as a consumer's evaluation about a brand's overall physical operation and the product's physical formation perfection. Third, attachment is defined as the comparative power of a consumer's positive opinions toward the brand. Fourth, value is referred to the perceived brand usefulness comparative to its costs, evaluated by the consumer. Fifth, trustworthiness is defined as the assurance a consumer puts in the 
firm and its communications.

The reasons for including the above five dimensions of brand equity in the HE sector are as follows. The social image is regarded as a crucial dimension due to the added value of the social reputation associated with the ownership or use of the brand. Performance is very important for all brands that reflect brand quality. Attachment is included because consumers develop emotional attachment with some brands. The selection of a brand depends on the perceptual balance between the price of a product and all its benefits, so it includes price/value. Trustworthiness is involved since consumers value the brands they trust.

Prior studies have addressed the vital role of brand experience in building the brand's image such as (De Chernatony and Cottam, 2006); in reflecting the overall quality assessment that mirrors the product/service performance like Srinivasan and Till (2002) and Paswan andSharms (2004); in building strong bonds and attachment towards the brand such as: (Khan and Rahman, 2015) and Pratomo and Magetsari (2018); in reflecting the brand's value and in fostering trust towards the brand for example (Khan and Fatma, 2017). Since, online brand experience has a critical role in the brand equity formation. Then, the researcher will focus on the role of online brand experience in rising social image, increasing performance expectations, growing attachment, improving value and trustworthiness. Thus, based on the above arguments, the researcher assumed the following hypotheses:

H3: Online brand experience has a positive impact on social image in the HE sector.

H4: Online brand experience has a positive impact on performance in the HE sector.

H5: Online brand experience has a positive impact on attachment in the HE sector.

H6: Online brand experience has a positive impact on value in the HE sector.

H7: Online brand experience has a positive impact on trustworthiness in the HE sector. 


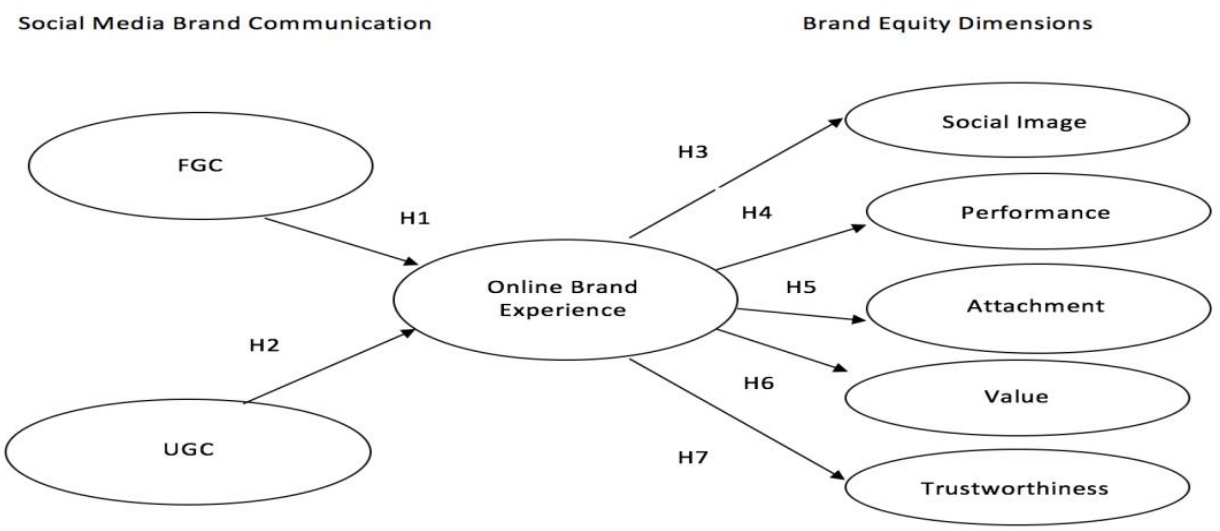

Figure 1: Conceptual Framework

\section{3- Methodology}

In this study, a quantitative approach was used to test the research hypotheses. The target population consists of the undergraduate students in the private and international institutions in Egypt. The sampling frame was not available to the researcher; thus a convenience sampling technique was used. An electronic questionnaire was distributed by using Google forums among undergraduate students via students' groups in private and international institutions in Cairo and Alexandria. A total of 399 electronic questionnaires were collected from 17 private and international universities from a total of 33 and then analyzed via Structural Equation Modeling (SEM), AMOS 22.

The students age ranged between 18 to 22 years' old who represent the Digital Natives generation who represent the main customers of the Internet and the technological innovations (McCorkindale, DiStaso, \& Sisco, 2013). The questionnaire started by asking the students to specify their university to fill in the questionnaire based on their selection. The questionnaire was classified in 4 main parts in addition to the demographic questions. All items of the research variables were adapted from early studies and modified to the HE sector. For example, the first part was designed to measure FGC, which consists of 4 items and the second part intended to measure UGC including 4 items. The items of both FGC and UGC were based on Bruhn et al. (2012) and Schivinski and Dabrowski (2015). The third part aimed to measure online brand 
experience that consists of 5 items from Morgan-Thomas and Veloutsou's (2013); and the last part directed to measure 5 brand equity dimensions comprising 17 items from (Lasser et al., 1995; \& Perera et al., 2020) as shown in the appendix. All replies were noted by using fivepoint Likert scale varying from " 1 " strongly disagree and " 5 " strongly agree.

\section{4- Results and Analysis}

The Structural Equation Modelling (SEM) was done based on AMOS 22. First of all, descriptive statistics for the research sample have been presented. Next, reliability of scales, convergent validity, discriminant validity, research variables descriptive statistics and measurement model fit indices have been measured before testing the research hypotheses.

\section{4-1 Descriptive Statistics for the Research Sample}

The sample size was 399 undergraduate students from private universities and international institutions with international agreements in the Egyptian HE sector. The students were from different 17 private and international institutions from distinctive faculties such as business administration, computer science, engineering, pharmacy, language and communication ranging from year 1 till year 5 depends on the faculty. $95 \%$ of the students range between age 18 till 21 years old. $57 \%$ of the students were female and $43 \%$ were male. Besides, $76 \%$ of them were above 15,000 L.E. average monthly household income.

\section{4-2 Reliability of Scales}

The reliability test is critical because it identifies the degree to which a scale produces reliable and consistent results if measurements are done repetitively. Table (1) presents the Cronbach's Alpha coefficients. From table (1), Cronbach's Alpha coefficients ranged between 0.838 and 0.938, which shows a good level of reliability as these values were more than the threshold value of 0.7 (Hair et al., 2014). 
Table 1: Reliability Analysis

\begin{tabular}{|c|c|}
\hline Variables names & $\begin{array}{c}\text { Cronbach's Alpha } \\
\text { coefficients }\end{array}$ \\
\hline FGC & 0.877 \\
\hline UGC & 0.896 \\
\hline Online brand experience & 0.844 \\
\hline Social image & 0.838 \\
\hline Performance & 0.922 \\
\hline Attachment & 0.938 \\
\hline Value & 0.878 \\
\hline Trustworthiness & 0.883 \\
\hline
\end{tabular}

\section{4-3 Validity of Scales}

Validity of scales was tested through convergent validity and discriminant validity.

\section{4-3-1 Convergent Validity}

The convergent validity was measured by using explanatory factor analysis (EFA) and confirmatory factor analysis (CFA) as indicated in table (2). From table (2), the EFA was assessed based on the principal component analysis to identify the validity of the research variables. Based on Hair et al. (2014), factor loadings of 0.5 or more are significant for sample sizes of 350 or greater. In this paper, the factor loadings of each item of the research variables were above the mentioned level ranging from 0.693 to 0.956 , which indicates the meaningful contribution of the items in measuring their variables. Besides, KaiserMeyer-Olkin (KMO) and Bartlett's Test were assessed in this paper as shown in table (2). According to Hair et al. (2010), KMO returns values are between 0 and 1 and the values closer to 1 are better. Moreover, a significant Bartlett's test of sphericity is required while $\mathrm{p}$ is less than 0.05 (Bartlett, 1951).

Additionally, the EFA was used to notice the unidimensionality of each construct. Unidimensionality is an indication that a single construct underlies a set of measures (Anderson and Gerbing, 1988). Based on Hair et al.(2010), the unidimensionality was stated by the Average Variance Extracted (AVE) that must be greater than 50\%. In this paper, the AVE values are greater than 50\% ranging from $62.182 \%$ to $89.079 \%$ as shown in table (2). Moreover, CFA by means of the maximum likelihood 
estimates was used to test the fitness of data in a hypothesized measurement model. In this paper, the CFA loading factor of each item of the research variables were ranging from 0.591 to 0.93 as shown in table (2), which is above 0.5 as mentioned by (Hair et al., 2014).

Table 2: Convergent Validity by Using EFA and CFA

\begin{tabular}{|c|c|c|c|c|c|c|}
\hline \multirow[b]{2}{*}{ Variables } & \multirow[b]{2}{*}{ Items } & \multicolumn{4}{|c|}{ EFA } & \multirow[b]{2}{*}{ 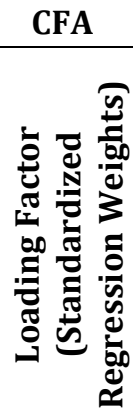 } \\
\hline & & 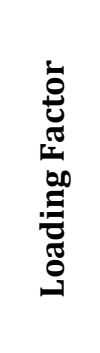 & 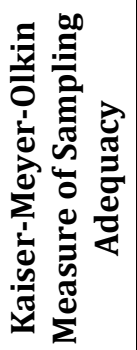 & 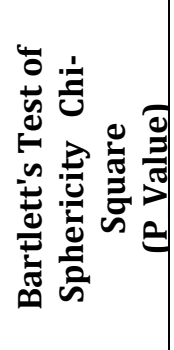 & 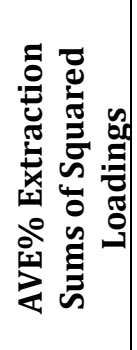 & \\
\hline \multirow{4}{*}{ Firm Generated content } & Q_1 & 0.877 & \multirow{4}{*}{0.800} & \multirow{4}{*}{$\begin{array}{c}856.018 \\
(0.000)\end{array}$} & \multirow{4}{*}{73.172} & 0.837 \\
\hline & Q_2 & 0.887 & & & & 0.863 \\
\hline & Q_3 & 0.867 & & & & 0.804 \\
\hline & Q 4 & 0.787 & & & & 0.708 \\
\hline \multirow{4}{*}{ User Generated content } & Q_5 & 0.877 & \multirow{4}{*}{0.842} & \multirow{4}{*}{$\begin{array}{c}947.168 \\
(0.000)\end{array}$} & \multirow{4}{*}{76.322} & 0.809 \\
\hline & Q_6 & 0.871 & & & & 0.821 \\
\hline & Q_7 & 0.842 & & & & 0.774 \\
\hline & Q_8 & 0.903 & & & & 0.9 \\
\hline \multirow{5}{*}{ Online brand experience } & Q_9 & 0.781 & \multirow{5}{*}{0.800} & \multirow{5}{*}{$\begin{array}{c}850.415 \\
(0.000)\end{array}$} & \multirow{5}{*}{62.182} & 0.742 \\
\hline & Q_10 & 0.782 & & & & 0.69 \\
\hline & Q_11 & 0.693 & & & & 0.591 \\
\hline & Q_12 & 0.808 & & & & 0.776 \\
\hline & Q_13 & 0.868 & & & & 0.832 \\
\hline \multirow{4}{*}{ Social image } & Q_14 & 0.789 & \multirow{4}{*}{0.765} & \multirow{4}{*}{$\begin{array}{c}662.279 \\
(0.000)\end{array}$} & \multirow{4}{*}{67.522} & 0.723 \\
\hline & Q_15 & 0.772 & & & & 0.654 \\
\hline & Q_16 & 0.879 & & & & 0.782 \\
\hline & Q_17 & 0.842 & & & & 0.846 \\
\hline \multirow{4}{*}{ Performance } & Q_18 & 0.916 & \multirow{4}{*}{0.843} & \multirow{4}{*}{$\begin{array}{c}1223.384 \\
(0.000)\end{array}$} & \multirow{4}{*}{81.045} & 0.886 \\
\hline & Q_19 & 0.928 & & & & 0.91 \\
\hline & Q_20 & 0.883 & & & & 0.855 \\
\hline & Q_21 & 0.873 & & & & 0.815 \\
\hline \multirow{3}{*}{ Attachment } & Q_22 & 0.941 & \multirow{3}{*}{0.760} & \multirow{3}{*}{$\begin{array}{c}1063.222 \\
(0.000)\end{array}$} & \multirow{3}{*}{89.079} & 0.924 \\
\hline & Q_23 & 0.956 & & & & 0.93 \\
\hline & Q_24 & 0.934 & & & & 0.891 \\
\hline \multirow{3}{*}{ Value } & Q_25 & 0.874 & \multirow{3}{*}{0.723} & & & 0.787 \\
\hline & Q_26 & 0.891 & & 646.939 & 80.449 & 0.848 \\
\hline & Q_27 & 0.924 & & $(0.000)$ & & 0.894 \\
\hline & Q_28 & 0.881 & & & & 0.856 \\
\hline Trustworthiness & Q_29 & 0.933 & 0.714 & 683.704 & 81.162 & 0.884 \\
\hline & Q_30 & 0.888 & & & & 0.805 \\
\hline
\end{tabular}




\section{4-3-2 Discriminant Validity}

To assess the discriminant validity of research variables, the square root of AVE for each variable was compared with its correlation with other variables (Sharma \& Patterson, 1999). Table (3) illustrates correlations and internal correlations. As shown in table (3), comparisons were done among square root of AVE (internal correlations) for each variable and its correlation coefficients with other variables. Based on the comparisons, significant correlations exist between research variables, but all these correlations are lower than the square root of AVE. For example, UGC and trustworthiness are correlated $(r=0.636)$, but the square roots of AVE of both variables are 0.874 and 0.901 , respectively. This means that respondents can discriminate between both variables while they are correlated. By examining this matrix, it has been found that respondents can discriminate between all research variables.

Table 3: Correlations \& Internal Correlations

\begin{tabular}{|l|c|c|c|c|c|c|c|c|}
\hline & FGC & UGC & $\begin{array}{c}\text { Online } \\
\text { brand } \\
\text { experience }\end{array}$ & $\begin{array}{c}\text { Social } \\
\text { image }\end{array}$ & Performance & Attachment & Value & Trustworthiness \\
\hline FGC & 0.859 & & & & & & & \\
\hline UGC & 0.697 & 0.874 & & & & & & \\
\hline $\begin{array}{l}\text { Online brand } \\
\text { experience }\end{array}$ & 0.392 & 0.425 & 0.789 & & & & & \\
\hline Social image & 0.362 & 0.494 & 0.678 & 0.822 & & & & \\
\hline Performance & 0.436 & 0.591 & 0.682 & 0.825 & 0.900 & & & \\
\hline Attachment & 0.423 & 0.548 & 0.684 & 0.776 & 0.908 & 0.944 & & \\
\hline Value & 0.426 & 0.414 & 0.580 & 0.714 & 0.636 & 0.673 & 0.897 & \\
\hline Trustworthiness & 0.686 & 0.636 & 0.615 & 0.665 & 0.677 & 0.720 & 0.719 & 0.901 \\
\hline
\end{tabular}

Note: the shaded sells containing the square root of AVE (internal correlations)

\section{4-4 Research Variables Descriptive Statistics}

After conducting the reliability \& validity tests. Descriptive statistics for the research variables have been presented in table (4). As shown in table (4), Skewness and Kurtosis indicate that the research variables are approximately distributed normal. 
Table 4: Descriptive Variables

\begin{tabular}{|c|c|c|c|c|c|}
\hline & Mean & Median & $\begin{array}{c}\text { Std. } \\
\text { Deviation }\end{array}$ & Skewness & Kurtosis \\
\hline FGC & 3.4530 & 3.5000 & .89007 & $-.576-$ & .457 \\
\hline UGC & 3.6078 & 3.5000 & .86819 & $-.607-$ & .645 \\
\hline $\begin{array}{c}\text { Online brand } \\
\text { experience }\end{array}$ & 3.4070 & 3.6000 & .87841 & $-.875-$ & .859 \\
\hline Social image & 3.5789 & 3.7500 & .84790 & $-.643-$ & .200 \\
\hline Performance & 3.7794 & 4.0000 & .92558 & $-.670-$ & .053 \\
\hline Attachment & 3.7469 & 4.0000 & 1.07363 & $-.671-$ & $-.330-$ \\
\hline Value & 3.0468 & 3.3333 & .96188 & $-.184-$ & $-.496-$ \\
\hline Trustworthiness & 3.4812 & 3.6667 & 1.03086 & $-.534-$ & $-.323-$ \\
\hline
\end{tabular}

From table (4), it has been shown that the average value of UGC (3.6078) is greater than the average value of FGC (3.453), meaning that the respondents perceived that the UGC has a great role than the FGC. Besides, among the five CBBE dimensions, it has been shown that the average value of the value dimension is lower than the other dimensions, indicating that the respondents are not satisfying with the university usefulness and value compared to its costs.

\section{4-5 The Research Model}

\section{4-5-1 Testing the Research Hypotheses}

The AMOS output for the model parameter estimates is presented in Table (5). Based on Hair et al. (2010), any number of a critical ratio (CR) above \pm 1.96 and $p$ value less than 0.05 is considered to be significant in the model. 
Table 5: The standardized Estimate, $C R$ and $P$ Value

\begin{tabular}{|c|c|c|c|c|c|c|c|c|c|}
\hline Number of & \multicolumn{3}{|c|}{ Research hypotheses } & \multirow{2}{*}{$\begin{array}{c}\text { Fstimate } \\
0.218\end{array}$} & \multirow{2}{*}{$\begin{array}{l}\text { S.E. } \\
0.106\end{array}$} & \multirow{2}{*}{$\begin{array}{c}\begin{array}{c}\text { Standardizod } \\
\text { Estimate } \\
\text { Regression weight }\end{array} \\
0.224\end{array}$} & \multirow{2}{*}{$\begin{array}{c}\text { CR } \\
2.066\end{array}$} & \multirow{2}{*}{$\begin{array}{c}\text { P Value } \\
0.039\end{array}$} & \multirow{2}{*}{$\begin{array}{c}\text { Results } \\
\text { Positive } \\
\text { Significant } \\
\text { Impact }\end{array}$} \\
\hline $\mathrm{H}_{1}$ & $\mathrm{OBE}$ & $<\cdots$ & FGC & & & & & & \\
\hline $\mathrm{H}_{2}$ & $\mathrm{OBE}$ & $<-$ & UGC & 0.35 & 0.088 & 0.431 & 3.99 & $\cdots$ & $\begin{array}{l}\text { Positive } \\
\text { Significant } \\
\text { Impact }\end{array}$ \\
\hline $\mathrm{H}_{3}$ & SI & $<-$ & OBE & 0.874 & 0.08 & 0.933 & 10.968 & $\ldots$ & $\begin{array}{l}\text { Positive } \\
\text { Significant } \\
\text { Impact } \\
\end{array}$ \\
\hline $\mathrm{H}_{4}$ & $\mathrm{P}$ & $<-$ & OBE & 1.116 & 0.09 & 0.891 & 12.378 & $\ldots$ & $\begin{array}{c}\text { Positive } \\
\text { Significant } \\
\text { Impact } \\
\end{array}$ \\
\hline $\mathrm{H}_{5}$ & A & $<-$ & OBE & 1.422 & 0.11 & 0.973 & 12.96 & *t. & $\begin{array}{c}\text { Positive } \\
\text { Significant } \\
\text { Impact } \\
\end{array}$ \\
\hline H6 & $\mathrm{V}$ & $<-$ & OBE & 0.893 & 0.089 & 0.796 & 10.027 & $\ldots$ & $\begin{array}{l}\text { Positive } \\
\text { Significant } \\
\text { Impact }\end{array}$ \\
\hline $\mathrm{H}_{7}$ & $\mathrm{~T}$ & $<-$ & OBE & 0.814 & 0.079 & 0.622 & 10.367 & $\cdots$ & $\begin{array}{c}\text { Positive } \\
\text { Significant } \\
\text { Impact }\end{array}$ \\
\hline
\end{tabular}

Note: FGC: Firm generated content, UGC: User generated content, OBE: Online brand experience, SI: Social image, P: Performance, A: Attachment, V: Value, T: Trustworthiness

The obtained statistics indicated that all the path coefficient results were significant, which means that the research hypotheses were supported at $5 \%$ significance level with p-values less than 0.05 (as showed in table 4). For the first research hypothesis, it has been shown that the FGC has a significant positive direct impact on online brand experience with a standardized estimate of 0.224 . This means that when the university generates satisfactory content on social media including images, videos and information about its education services, this will create favorable students' online brand experience. For the second hypothesis, it has been shown that the UGC has a significant positive direct impact on online brand experience with a standardized estimate of 0.431 . This means that when the user generates inspiring content on social media such as posts, comments, and positive feedback about the university, this will have a great impact on developing students' online brand experience. Additionally, it has been found that the UGC has more impact than the FGC on online brand experience in the Egyptian (HE) institutions. The students' posts, reviews and comments have a great impact on creating and constructing the students' online brand experience. For the third hypothesis, it has been found that online brand experience has a significant positive direct impact on social image with standardized estimate of 10.968. This means that when students have a constructive 
online brand experience towards the university, this will impact positively their perception towards the university's image. For the fourth hypothesis, it has been found that online brand experience has a significant positive direct impact on the university performance with standardized estimate of 12.378 . This means that when there is a favorable students' online brand experience, this will help to perceive good performance of the university. For the fifth hypothesis, it has been found that online brand experience has the greatest significant positive direct impact on the attachment with standardized estimate of 12.96, which means that the more promising and constructing online brand experience, the more attachment the student will have towards the university. For the sixth hypothesis, it has been found that online brand experience has a significant positive direct impact on the value with standardized estimate of 10.027. This means that when students have promising and satisfactory online brand experience, this will create a positive perception towards the university usefulness and value compared to its costs. For the seventh hypothesis, it has been found that online brand experience has a significant positive direct impact on the trustworthiness with standardized estimate of 10.367. This means that when students have fruitful online brand experience, this will help them to build their confidence and trust towards the university.

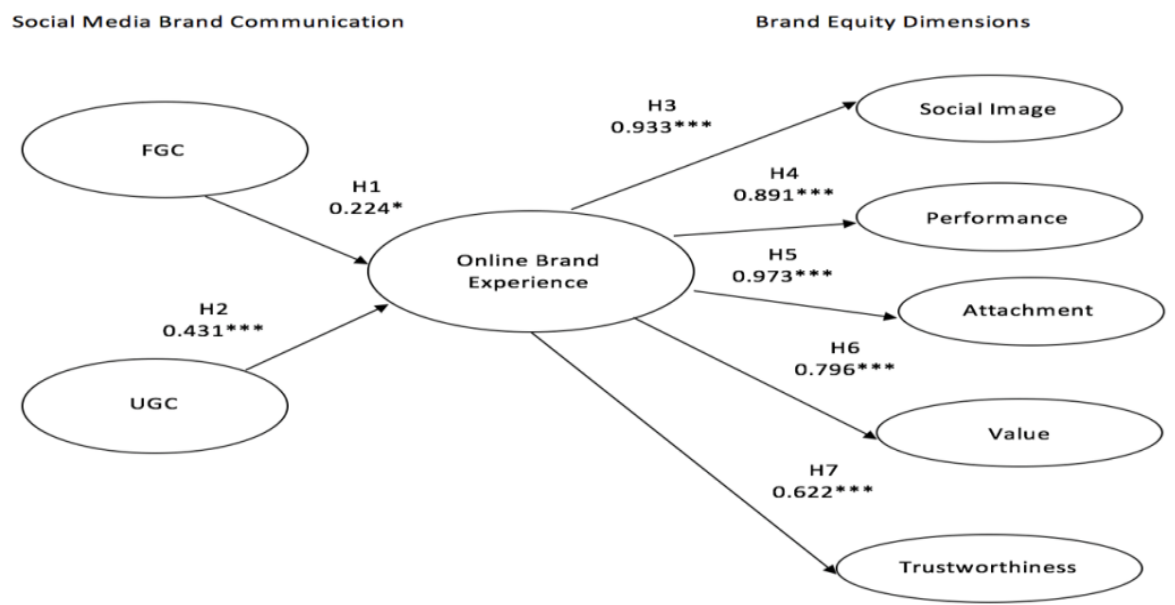

Pls note: *significant at $\mathrm{p}$-value $<0.05$ and $* * *$ significant at $\mathrm{p}$-value $<0.001$

Figure 2: Final Research Model 


\section{4-5-2 Indirect Effects}

This section will examine the indirect effects. As presented in table (6), there are indirect effects from UGC on the CBBE dimensions namely, trustworthiness, value, attachment, performance and social image via online brand experience. However, there are no indirect effects from FGC on the CBBE dimensions namely, trustworthiness, value, attachment, performance and social image via online brand experience.

Table 6: Standardized Indirect Effects

\begin{tabular}{|c|c|c|c|c|c|c|c|c|c|}
\hline \multicolumn{5}{|c|}{ Indirect Effects } & \multirow{2}{*}{$\begin{array}{l}\text { Estimate } \\
0.285\end{array}$} & \multirow{2}{*}{$\begin{array}{c}\begin{array}{c}\text { Standardized } \\
\text { istimate }\end{array} \\
0.268^{*}\end{array}$} & \multirow{2}{*}{$\begin{array}{c}\text { Standard } \\
\text { lirrors }\end{array}$} & \multirow{2}{*}{$\frac{\text { P. value }}{0.004}$} & \multirow{2}{*}{$\begin{array}{c}\text { Results } \\
\text { Positive Significant impact }\end{array}$} \\
\hline UGC. & $\ldots$ & $O B E$ & $\ldots$ & T. & & & & & \\
\hline UGC. & $\ldots$ & $O B E$ & $->$ & V. & 0.313 & 0.343 & 0.116 & 0.004 & Positive Significant impact \\
\hline UGC. & $\rightarrow$ & $O B E$ & $\rightarrow>$ & A. & 0.497 & 0.42 & 0.186 & 0.005 & Positive Significant impact \\
\hline UGC. & $\rightarrow$ & $O B E$ & $\rightarrow>$ & P. & 0.39 & 0.384 & 0.138 & 0.005 & Positive Significant impact \\
\hline UGC. & $\ldots$ & $O B E$ & $\ldots$ & SI. & 0.306 & 0.403 & 0.112 & 0.004 & Positive Significant impact \\
\hline $\mathrm{FGC}$ & $\rightarrow>$ & $O B E$ & $\rightarrow>$ & T. & 0.178 & 0.139 & 0.159 & 0.182 & insignificant impact \\
\hline FGC & $\rightarrow$ & $O B E$ & $\rightarrow>$ & V. & 0.195 & 0.178 & 0.175 & $0.18_{4}$ & insignificant impact \\
\hline $\mathrm{FGC}$ & $\rightarrow>$ & $O B E$ & $\rightarrow>$ & A. & 0.31 & 0.218 & 0.291 & 0.189 & insignificant impact \\
\hline FGC & $\rightarrow>$ & $O B E$ & $\ldots$ & P. & 0.243 & 0.199 & 0.224 & 0.19 & insignificant impact \\
\hline $\mathrm{FGC}$ & $\rightarrow$ & $O B E$ & $\ldots$ & SI. & 0.191 & 0.209 & 0.175 & 0.186 & insignificant impact \\
\hline
\end{tabular}

Note: FGC: Firm generated content, UGC: User generated content, OBE: Online brand experience, SI: Social image, P: Performance, A: Attachment, V: Value, T: Trustworthiness

From table (6), the indirect effects from UGC on the CBBE dimensions via online brand experience are positive and significant at 0.05 significance level. The UGC shows the strongest indirect effect on the attachment (standardized estimate $=0.42$ ) via the online brand experience, meaning that the content generated by users play a great role on the student's attachment towards the university via developing a favorable online brand experience. However, the indirect effects from FGC on CBBE dimensions via online brand experience are not supported, meaning that the content generated by the firm did not impact the trustworthiness, value, attachment, performance and social image 
via online brand experience, which means that only the UGC has a great impact on trustworthiness, value, attachment, performance and social image via online brand experience.

\section{4-5-3 The Mediation Role}

Table 7: The Mediation Role

\begin{tabular}{|c|c|c|c|c|c|c|c|c|}
\hline $\begin{array}{l}\text { The mediation } \\
\text { role of (OBE) } \\
\text { in the relation }\end{array}$ & $\begin{array}{l}\text { Necessary conditions } \\
\text { Direct Effects }\end{array}$ & \multicolumn{5}{|c|}{$\begin{array}{l}\text { Sufficient condition } \\
\text { Indirect Effect }\end{array}$} & $\begin{array}{l}\text { Direct Effects } \\
\text { Between variables }\end{array}$ & \multirow{2}{*}{$\begin{array}{c}\text { Decision } \\
F M\end{array}$} \\
\hline UGC.,T. & $\begin{array}{llll}\text { UGC. } & \leftarrow \text { OBE } & \checkmark \\
\text { OBE } & \leftarrow \text { T. } & \checkmark\end{array}$ & UGC. & $\leftarrow$ & OBE & $\leftarrow$ & T. $\quad \checkmark$ & UGC. $\leftarrow$ T. $\square$ & \\
\hline UGC.,V. & $\begin{array}{llll}\text { UGC. } & \leftarrow \text { OBE } & \checkmark \\
\text { OBE } & \leftarrow & \text { V } & \checkmark\end{array}$ & UGC. & $\leftarrow$ & $\mathrm{OBF}$ & $\leftarrow$ & v. $\quad \checkmark$ & UGC. $\leftarrow$ V. $\square$ & $\mathrm{FM}$ \\
\hline UGC.,A. & $\begin{array}{llll}\text { UGC. } & \leftarrow \text { OBE } \\
\text { OBE } & \leftarrow & A & \checkmark\end{array}$ & UGC. & & $\mathrm{OBE}$ & $\leftarrow$ & A. $\checkmark \checkmark$ & UGC. $\leftarrow$ A. $\checkmark$ & $\mathrm{PM}$ \\
\hline UGC.,P. & $\begin{array}{llll}\text { UGC } & \leftarrow \text { OBE } \\
\text { OBE } & \leftarrow \text { P. }\end{array}$ & UGC. & $\leftarrow$ & $\mathrm{OBE}$ & $\leftarrow$ & P. & UGC. $\leftarrow$ P. $\checkmark$ & $\mathrm{PM}$ \\
\hline UGC.SI. & $\begin{array}{llll}\text { UGC. } & \leftarrow & \text { OBE } & \checkmark \\
\text { OBE } & \leftarrow & \text { SI. } & \checkmark\end{array}$ & UGC. & 6 & $\mathrm{OBE}$ & $\leftarrow$ & SI. $\checkmark$ & UGC. $\leftarrow$ S1. $\checkmark$ & PM \\
\hline FGC, $\mathrm{T}$. & $\begin{array}{llll}\text { FGC. } & \leftarrow & \text { OBE } & \checkmark \\
\text { OBE } & \leftarrow & \text { T. } & \checkmark\end{array}$ & FGC & & $\mathrm{OBE}$ & $\leftarrow$ & T. $\mathbf{x}$ & FGC $\leftarrow$ T. $\checkmark$ & NM \\
\hline FGC,V. & $\begin{array}{llll}\text { FGC } & \leftarrow \text { OBE } & \checkmark \\
\mathrm{OBE} & \leftarrow & \mathrm{V} & \checkmark\end{array}$ & FGC & $\leftarrow$ & $\mathrm{OBE}$ & $\leftarrow$ & v. $\mathbf{x}$ & FGC $\leftarrow$ v. $\otimes$ & NM \\
\hline FGC,A. & $\begin{array}{llll}\text { FGC. } & \leftarrow & \text { OBE } & \checkmark \\
\mathrm{OBE} & \leftarrow & \mathrm{A} & \checkmark\end{array}$ & FGC & & $\mathrm{OBE}$ & $\leftarrow$ & A. $\mathrm{x}$ & FGC $\leftarrow$ A. $\checkmark$ & NM \\
\hline FGC,P. & $\begin{array}{llll}\text { FGC. } & \leftarrow & \text { OBE } & \checkmark \\
\text { OBE } & \leftarrow & \text { P. } & \checkmark\end{array}$ & FGC & & $\mathrm{OBE}$ & $\leftarrow$ & P. 区 & FGC $\leftarrow$ P. $\checkmark$ & NM \\
\hline FGC SI. & $\begin{array}{llll}\text { FGC } & \leftarrow & \text { OBE } & \checkmark \\
\text { OBE } & \leftarrow & \text { SI. } & \checkmark\end{array}$ & FGC & 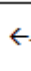 & $\mathrm{OBE}$ & $\leftarrow$ & S1. $\mathbf{\square}$ & FGC $\leftarrow$ SI. $\checkmark$ & NM \\
\hline
\end{tabular}

The above table identifies the role of online brand experience as a mediator. First of all, it identifies the role of online brand experience as a mediator between UGC and the CBBE dimensions. As shown in the table, the necessary and sufficient conditions are achieved in the relationship between them. In more details, the online brand experience plays a full mediation role between UGC and two of the CBBE dimensions namely, value and trustworthiness and partially mediation role between UGC and the other CBBE dimensions namely, attachment, performance and social image. However, the online brand experience did not play a mediator role between the FGC and the CBBE dimensions and this is because the sufficient conditions are not met, meaning that the UGC has a great impact on trustworthiness, value, attachment, performance and social image via online brand experience. 


\section{5- Discussion}

Based on the research findings, it has been shown that FGC and UGC have a significant positive direct impact on students' online brand experience in the Egyptian HE sector. These findings tie commonly with the line of thought of Kudeshia and Kumar (2017) and Tuten and Mintu-Wimsalt (2018) and Nisar et al. (2020) who mentioned the powerful role of social media in creating brand experience since the online world is becoming the core platform to share experience. Especially the UGC has been found to have the greatest impact in developing students' online brand experience, which means that students are more induced by other users' generated opinions, feedback and comments than videos, images and posts that are generated by the university. This finding matches with the theory of social influence that proposes that people are more influenced by other users' perspectives (Hsiao \& Chiou, 2012). Moreover, this finding was supported by Duan et al. (2008); Sijoria et al. (2019) and Nisar et al. (2020) who mentioned that in the era of social media, which is characterized by the availability of information, customers search for a high level of satisfaction so they depend mainly on friends and other users' reviews to form their experience before purchasing or using products/services because for them the most beneficial source of information is the customer instead of the firms.

Moreover, it has been found that the online brand experience has a significant positive direct impact on social image, performance, attachment, value and trustworthiness. First, it has been indicated that the online brand experience has the greatest impact on students' attachment towards the university, which means that the more favorable, promising and encouraging the online brand experience, the more the students will be attached and devoted to the university. This finding is in line with the prior studies such as Khan and Rahman (2015) and Pratomo and Magetsari (2018) who mentioned that the constructive online brand experience helps to generate more attachment, connection and loyalty towards the brand. Second, it has been found that online brand experience has a significant positive direct impact on social image. This means that affirmative online brand experience helps to develop and improve the university's social image. This finding is in line with De Chernatony and Cottam (2006) who declared that experience in services 
represent a crucial contribution in developing the image of the brand.

Third, the significant positive direct impact of online brand experience on brand performance shows that the constructive online brand experience will impact certainly the perception of the students towards the university's performance, which was supported by Srinivasan and Till (2002) and Paswan and Sharma (2004) who mentioned that customers' experience towards the brand impacts its general quality assessment that reflects the product/service performance. Fourth, it has been found that online brand experience has a significant positive direct impact on the value, which means that the positive experience helps to form a good perception regarding the balance between the price of the university's education services relative to its related benefits. This finding is in line with Chinomona (2013) and Brakus et al. (2009) who mentioned generally that online brand experience will generate more value to customers. Fifth, concerning the trustworthiness, it has been found that online brand experience plays a vital role in developing trust towards the university. This finding matches with the previous studies of Khan and Fatma (2017) and Pratomo and Magetsari (2018) who stated that the more favorable experience felt by customers, the greater the trust regarding the brand. Concerning the mediator role of online brand experience between "FGC and UGC" from one side and brand equity dimensions namely: "social image, performance, attachment, value and trustworthiness" from the other side. It has been found that online brand experience did not act as a mediator between FGC and brand equity dimensions. This means that the FGC did not impact "social image, performance, attachment, value and trustworthiness" via the online brand experience. For students, the FGC helps them to know about the university and to develop an online brand experience but its impact does not extend to influence the 5 CBBE dimensions via the online brand experience. However, the online brand experience acts as a mediator between UGC and CBBE dimensions. This means that UGC has an impact on the CBBE dimensions via online brand experience. For students, the UGC helps them to form an online brand experience, which will impact the CBBE dimensions.

These findings were supported by Mourad et al. (2019) thoughts who mentioned that in the HE sector, students are looking for the positive 
word of mouth generated by students, since students represent the beneficial source of information than the information generated by the university. This idea was also supported by Hsiao and Chiou (2012); Ren et al. (2012) and Shareef et al. (2019) who asserted that UGC are more trusty than FGC. They mentioned that users favor to read users' reviews more than information posted by the firm since they trust more the users who are independent from the firm control. Therefore, users are more attracted by the demonstrations of products/services who have already been used by others than by FGC. Thus, FGC has a poorer convincing impact than that of the UGC.

\section{6- Implications}

This research provides theoretical and practical implications. Theoretically, previous studies such as Mourad et al. (2019) mentioned that brand equity determinants in HE institutions is scare due to the rising importance of HE branding. Therefore, this research responds to the request of previous studies by focusing on five determinants of brand equity in the HE sector based on students' perspective. These determinants are: social image, performance, attachment, value and brand trust. Additionally, Beig and Khan (2018) and Dwivedi et al. (2020) mentioned the importance role of social media brand communication on building online brand experience and stated that this area needs more focus. Therefore, the researcher focused on the two forms of social media brand communication FGC and UGC on building online brand experience, which will lead to enhance brand equity in one study.

Practically, this research indicated the significance role of UGC in developing online brand experience, which helps to build students' trust and attachment, shape students' perception towards universities' performance and mirror social image as well as reflect the balance between the university's price and its relative benefits. Therefore, this research provides precious understandings that should be taken into concern. Necessary, the marketing managers in the HE sector should give more attention to build positive CBBE dimensions to their universities to stand high in the cloud in today's severe competition. This will be achievable by giving more weight to students by creating, maintaining credibility and delivering university's promises, since students represent 
the powerful tool in spreading and sharing their experience via social media. If they share positive, unique and favorable experience through their feedback, comments or posts, this will create trust, indicate good university's performance, increase attachment, mirror good social image, reflect good value of money towards the university, which will enhance the university's brand equity. Besides, marketing managers should communicate clearly their messages in a way that reflects the education services provided by their university and avoid making high expectations.

\section{7- Conclusion}

The severe competition that exists in today's Egyptian HE sector highlights the crucial role of marketing communication tools, particularly the social media brand communication tool since this tool targets more the age group between 18 to 22 years' old who represent the Digital Natives generation who characterize the main customers of universities. Thus, this study focused on the social media brand communication including FGC and UGC to examine their impact on online brand experience, which may lead to high brand equity based on students' perspectives. At the end, it has been found that UGC has a great impact on building online brand experience more than FGC. This means that universities should give more attention to their students by dealing with them as an important asset to ensure that they received the needed value. Additionally, the results showed that online brand experience acts as a mediator only between UGC and CBBE dimensions. However, FGC impacts the online brand experience but its impact is not extended to build CBBE dimensions via online brand experience. This confirms the greatest importance of UGC like students' reviews, comments, posts and any feedback in developing online brand experience, which will impact the brand equity that emphasizes the stronger convincing impact of UGC than that of FGC.

\section{8- Limitations and Future Directions}

This research focused on the Egyptian HE sector. Further research can examine this research model in other service industries like banking sector, telecommunication sector and also in other countries. In addition, this research focused on social media brand communication based on 
one main platform, which is Facebook. Future research can examine other platforms than Facebook because different platforms may lead to different results. Furthermore, this research used a non-probability sampling technique, which is a convenience sampling technique. Future research can use a probability sampling technique. Finally, this research examined the impact of social media brand communication including the two types FGC and UGC on online brand experience, which helps build CBBE dimensions. Future research can examine the impact of different social media content forms (like: videos, photos) on online brand experience and CBBE dimensions.

\section{9- Recommendations}

This research presents valuable recommendations particularly to the HE institutions to build and improve their brand equity within the highly competitive environment and the rapidly changing digital marketplace. First, the HE institutions should spread favorable and constructive content via social media since it is considered as the main promotional tool in today's business environment to create favorable online brand experience. Second, they should be more marketing oriented by focusing on their students to satisfy their needs since they represent the main customers. Third, they have to develop added values more than the other competitors to meet and exceed their students' expectations. Consequently, students will be encouraged to spread positive comments, reviews and posts on social media, which will create more effective student experience that will help to reflect respectable image, good performance, increase students' attachment, increase value and build trust.

\section{References}

Aaker, D.A., \& Equity, M.B. (1991). Measuring Brand Equity: Capitalizing on the Value of a Brand Name, The Free Press, New York, 28, 35-37.

Alalwan, A.; Rana, N.; Dwivedi, Y., \& Algharabat, R. (2017). Social media in marketing: A review and analysis of the existing literature. Telematics and Informatics, 34 (7), 1177-1190. https://doi.org/10.1016/j.tele. 2017.05.008 
Alam, W., \& Saeed, T. (2016). Impact of brand knowledge on brand equity of universities in Khyber Pakhtunkhwa. Abasyn University Journal of Social Sciences, 9(1), 16-30.

Andreini, D.; Pedeliento, G.; Zarantonello; L., \& Solerio, C. (2018). A renaissance of brand experience: Advancing the concept through a multi-perspective analysis. Journal of Business Research, 91, 123-133. doi: 10.1016/j.jbusres.2018.05.046

Ashley, C., \& Tuten, T. (2014). Creative Strategies in Social Media Marketing: An Exploratory Study of Branded Social Content and Consumer Engagement. Psychology \& Marketing, 32(1), 1527. doi: $10.1002 /$ mar.20761

Bambauer-Sachse, S., \& Mangold, S. (2011). Brand equity dilu- tion through negative online word-of-mouth communication. Journal of Retailing and Consumer Services, 18(1), 38-45.

Bartlett, M. (1951). The Effect of Standardization on a $\chi 2$ Approximation in Factor Analysis. Biometrika, 38(3/4), 337. doi: $10.2307 / 2332580$

Beig, F., \& Khan, M. (2018). Impact of Social Media Marketing on Brand Experience: A Study of Select Apparel Brands on Facebook. Vision: The Journal of Business Perspective, 22(3), 264-275. https://doi.org/ 10.1177/0972262918785962

Beig, F., \& Nika, F. (2019). Impact of Brand Experience on Brand Equity of Online Shopping Portals: A Study of Select E-Commerce Sites in the State of Jammu and Kashmir. Global Business Review, 097215091983604. doi: 10.1177/0972150919836041

Berry, L. (2000). Cultivating service brand equity. Journal of The Academy of Marketing Science, 28(1), 128-137. https://doi.org/10.1177/0092070300 281012

Brakus, J.J.; Schmitt, B.H., \& Zarantonello, L. (2009). Brand experience: what is it? How is it measured? Does it affect loyalty? Journal of Marketing, 73 (3), 52-68.

Bruhn, M.; Schoenmueller, V., \& Schäfer, D. (2012). Are social media replacing traditional media in terms of brand equity creation? 
Management Research Review, 35(9), 770-790. doi: 10.1108/01409171211255948

Chen-Yu, J.; Cho, S., \& Kincade, D. (2016). Brand perception and brand repurchase intent in online apparel shopping: An examination of brand experience, image congruence, brand affect, and brand trust. Journal of Global Fashion Marketing, 7(1), 30-44. doi: 10.1080/20932685.2015.1110042

Chinomona, R. (2013). The Influence of Brand Experience on Brand Satisfaction, Trust and Attachment in South Africa. International Business \& Economics Research Journal (IBER), 12(10), 1303. doi: 10.19030/iber. v12i10.8138

De Chernatony, L., \& Cottam, S. (2006). Why are all financial services brands not great? Journal of Product \& Brand Management, 15(2), 88-97. doi: 10.1108/10610420610658929

De Chernatony, L., \& Dall'Olmo Riley, F. (1999). Experts' Views About Defining Services Brands and the Principles of Services Branding. Journal of Business Research, 46(2), 181-192. doi: 10.1016/s0148-2963(98)00021-6

Duan, W.; Gu, B., \& Whinston, A. (2008). Do online reviews matter? - An empirical investigation of panel data. Decision Support Systems, 45(4), 1007-1016. doi: 10.1016/j.dss.2008.04.001

Dwivedi, Y.; Ismagilova, E.; Hughes, D.; Carlson, J.; Filieri, R., \& Jacobson, J. et al. (2020). Setting the future of digital and social media marketing research: Perspectives and research propositions. International Journal of Information Management, 102168. https://doi.org/ 10.1016/ j.ijinfomgt.2020.102168

Egypt's education system is by far the largest in the region - Brussels Research Group. (2021). Retrieved 28 March 2021, from https:// brusselsresearchgroup.org/egypts-educationsystem-is-by-far-the-largest-in-the-region/ 
Egyptian Higher Education Report, Statistics Details. (2021). Retrieved 28 March 2021, from http://portal.mohesr.gov.eg/areg/Pages/StatisticsDetails. aspx? folder=/ar-eg/DocLib/2018الجامعات الخاصة 2017/20\%

Ekinci, Y., \& Hosany, S. (2006). Destination Personality: An Application of Brand Personality to Tourism Destinations. Journal of Travel Research, 45(2), 127-139. doi: 10.1177/0047287506291603

Facebook: active users worldwide / Statista. Statista. (2020). Retrieved 31 August 2020, from https://www.statista.com/statistics/264810/number-ofmonthly-active-facebook-users- worldwide/.

Farquhar, P.H. (1989). Managing brand equity. Marketing Research. American Marketing Association, 1, 24-33.

Filo, K.; Lock, D., \& Karg, A. (2015). Sport and social media research: A review. Sport Management Review, 18(2), 166-181. doi: 10.1016/j.smr.2014.11. 001

Godey, B.; Manthiou, A.; Pederzoli, D.; Rokka, J.; Aiello, G.; Donvito, R., \& Singh, R. (2016). Social media marketing efforts of luxury brands: Influence on brand equity and consumer behavior. Journal of Business Research, 69(12), 5833-5841. doi: 10.1016/j.jbusres.2016.04.181

Hair, J.; Black, W.; Babin, B., \& Anderson, R. (2010). Multivariate data analysis (7th ed.). New Jersey: Prentice.

Hair, J.; Lukas, B.; Roberts, K., \& Lee-Lukas, S. (2014). Marketing research. North Ryde, NSW: McGraw-Hill Education.

Heckman, S., \& Montalto, C. (2016). Consumer Risk Preferences and Higher Education Enrollment Decisions. Journal of Consumer Affairs, 52(1), 166-196. doi: 10.1111/joca.12139

Hsiao, C., \& Chiou, J. (2012). The effect of social capital on community loyalty in a virtual community: Test of a tripartite-process model. Decision Support Systems, 54(1), 750-757. doi: 10.1016/j.dss.2012.09.003 
Iglesias, O.; Markovic, S.; Singh, J., \& Sierra, V. (2017). Do Customer Perceptions of Corporate Services Brand Ethicality Improve Brand Equity? Considering the Roles of Brand Heritage, Brand Image, and Recognition Benefits. Journal of Business Ethics, 154(2), 441-459. doi: 10.1007/s10551-017-3455-0

Jacobson, J.; Gruzd, A., \& Hernández-García, Á. (2020). Social media marketing: Who is watching the watchers? Journal of Retailing and Consumer Services, 53. https://doi.org/10.1016/j.jretconser.2019.03.001

Jung, H., \& Soo, M. (2012). Exploring the Mediating Effect of Brand Relationship Quality in the Service Brand Equity and Brand Resonance Linkage. Jurnal Pengurusan, 36 (1), 123-134. doi: 10.17576/ pengurusan-2012-36-11

Kaplan, A., \& Haenlein, M. (2010). Users of the world, unite! The challenges and opportunities of Social Media. Business Horizons, 53(1), 59-68. doi: 10.1016/j.bushor.2009.09.003

Keller, K. (1993). Conceptualizing, Measuring, and Managing CustomerBased Brand Equity. Journal of Marketing, 57(1), 1. doi: $10.2307 / 1252054$

Khan, I., \& Fatma, M. (2017). Antecedents and outcomes of brand experience: an empirical study. Journal of Brand Management, 24(5), 439-452. doi: 10.1057/s41262-017-0040-x

Khan, I., \& Rahman, Z. (2015). A review and future directions of brand experience research. International Strategic Management Review, 3(1-2), 1-14. doi: 10.1016/j.ism.2015.09.003

Khoshtaria, T.; Datuashvili, D., \& Matin, A. (2020). The impact of brand equity dimensions on university reputation: an empirical study of Georgian higher education. Journal of Marketing for Higher Education, 30(2), 239-255. doi: $10.1080 / 08841241.2020 .1725955$ 
Kietzmann, J.; Hermkens, K.; McCarthy, I., \& Silvestre, B. (2011). Social media? Get serious! Understanding the functional building blocks of social media. Business Horizons, 54(3), 241-251. doi: 10.1016/j.bushor.2011.01. 005

Kudeshia, C., \& Kumar, A. (2017). Social eWOM: does it affect the brand attitude and purchase intention of brands? Management Research Review, 40(3), 310-330. doi: 10.1108/mrr-07-20150161

Lassar, W.; Mittal, B., \& Sharma, A. (1995). Measuring customer-based brand equity. Journal of Consumer Marketing, 12(4), 11-19.

Le, T.; Dobele, A., \& Robinson, L. (2019). Information sought by prospective students from social media electronic word-ofmouth during the university choice process. Journal of Higher Education Policy and Management, 41(1), 18-34. https://doi.org/10.1080/1360080x.2018. 1538595

Leong, V.; Hibbert, S., \& Ennew, C. (2018). Communicating value to enhance service visualization. Journal of Services Marketing, 32(6), 645-656. doi: 10.1108/jsm-04-2017-0114

Lipsman, A.; Mudd, G.; Rich, M., \& Bruich, S. (2012). The Power of "Like". Journal of Advertising Research, 52(1), 40-52. doi: 10.2501/jar52-1-040-052

Lomer, S.; Papatsiba, V., \& Naidoo, R. (2018). Constructing a national higher education brand for the UK: positional competition and promised capitals. Studies in Higher Education, 43(1), 134-153.

McCorkindale, T.; Distaso, M., \& Sisco, H. (2013). How Millennials are Engaging and Building Relationships with Organizations on Facebook. The Journal of Social Media in Society, 2(1), 66-87.

Menictas, C.; Wang, P., \& Louviere, J. (2012). Assessing the Validity of Brand Equity Constructs. Australasian Marketing Journal, 20(1), 3-8. doi: 10.1016/j.ausmj.2011.10.008

Messner, W. (2020). Cultural and individual differences in online reviews. Journal of International Consumer Marketing, 32(5), 127. 
Morgan, T.A., \& Veloutsou, C. (2013). Beyond technology acceptance: brand relationships and online brand experience. Journal of Business Research, 66 (1), 21-27.

Mourad, M.; Ennew, C., \& Kortam, W. (2011). Brand equity in higher education. Marketing Intelligence \& Planning, 29(4), 403-420. https://doi.org/ 10.1108/02634501111138563

Mourad, M.; Meshreki, H., \& Sarofim, S. (2019). Brand equity in higher education: comparative analysis. Studies in Higher Education, 45(1), 209-231.

https://doi.org/10.1080/03075079.2019.1582012

Muhmurti, S., \& Selvanayagam, G. (2019). Brand equity in selecting a private higher education institution in Klang valley. BERJAYA Journal of Services \& Management, 12 (July 2019), 78-89.

Nisar, T.; Prabhakar, G.; Ilavarasan, P., \& Baabdullah, A. (2020). Up the ante: Electronic word of mouth and its effects on firm reputation and performance. Journal of Retailing and Consumer Services, 53, 101726. doi: 10.1016/j.jretconser.2018.12.010

Number of social media users worldwide / Statista. Statista. (2020). Retrieved $31 \quad$ August 2020, from https://www.statista.com/statistics/278414/ number-ofworldwide-social-network- users/.

Paswan, A., \& Sharma, D. (2004). Brand-country of origin (COO) knowledge and COO image: investigation in an emerging franchise market. Journal of Product \& Brand Management, 13(3), 144-155. doi: 10.1108 /10610420410538041

Perera, C.; Nayak, R., \& Nguyen, L. (2020). Social brand engagement and brand positioning for higher educational institutions: an empirical study in Sri Lanka. Journal of Marketing for Higher Education, 1-18. doi: 10.1080/08841241.2020.1841068

Perera, C.; Nayak, R., \& Nguyen, L. (2020). Social brand engagement and brand positioning for higher educational institutions: an empirical study in Sri Lanka. Journal of Marketing for Higher Education, 1-18. doi: 10.1080/08841241.2020.1841068 
Pratomo, L., \& Magetsari, O. (2018). Online Brand Experience: Drivers and Consequences. Jurnal Dinamika Manajemen, 9(2), 218-227. doi: $10.15294 / j d m$. v9i2.15192

Prensky, M. (2001). Digital Natives, Digital Immigrants Part 1. On The Horizon, 9(5), 1-6. doi: 10.1108/10748120110424816

Ramanathan, R.; Ramanathan, U., \& Hsiao, H. (2012). The impact of ecommerce on Taiwanese SMEs: Marketing and operations effects. International Journal of Production Economics, 140(2), 934-943. doi: 10.1016/j.ijpe.2012.07.017

Ren, Y.; Harper, F.; Drenner, S.; Terveen, L.; Kiesler, S.; Riedl, J., \& Kraut, R. (2012). Building Member Attachment in Online Communities: Applying Theories of Group Identity and Interpersonal Bonds. MIS Quarterly, 36(3), 841. doi: $10.2307 / 41703483$

Schivinski, B., \& Dabrowski, D. (2015). The impact of brand communication on brand equity through Facebook. Journal of Research in Interactive Marketing, 9(1), 31-53. doi: 10.1108/jrim-02-2014-0007

Shamim, A., \& Mohsin Butt, M. (2013). A critical model of brand experience consequences. Asia Pacific Journal of Marketing and Logistics, 25(1), 102-117. doi: 10.1108/13555851311290957

Shareef, M.; Mukerji, B.; Dwivedi, Y.; Rana, N., \& Islam, R. (2019). Social media marketing: Comparative effect of advertisement sources. Journal of Retailing and Consumer Services, 46, 58-69. doi: 10.1016/j.jretconser. 2017.11.001

Sharma, N., \& Patterson, P. (1999). The impact of communication effectiveness and service quality on relationship commitment in consumer, professional services. Journal of Services Marketing, 13(2), 151-170. doi: 10.1108/08876049910266059 
Sijoria, C.; Mukherjee, S., \& Datta, B. (2018). Impact of the antecedents of electronic word of mouth on consumer based brand equity: a study on the hotel industry. Journal of Hospitality Marketing \& Management, 28(1), 1-27. doi: $10.1080 / 19368623.2018 .1497564$

Social Media Stats Egypt / StatCounter Global Stats. StatCounter Global Stats. (2020). Retrieved 31 August 2020, from https://gs.statcounter.com/ social-media-stats/all/egypt.

Srinivasan, S., \& Till, B. (2002). Evaluation of search, experience and credence attributes: role of brand name and product trial. Journal of Product \& Brand Management, 11(7), 417-431. doi: $10.1108 / 10610420210451616$

Stojanovic, I., Andreu, L., \& Curras-Perez, R. (2018). Effects of the intensity of use of social media on brand equity an empirical study in a tourist destination. European Journal of Management and Business Economics, 27(1), 83-100. doi:10.1108/ejmbe-112017-0049

Tafesse, W. (2015). Content strategies and audience response on Facebook brand pages. Marketing Intelligence \& Planning, 33(6), 927-943. doi: 10.1108/mip-07-2014-0135

Tuten, T., \& Mintu-Wimsatt, A. (2018). Advancing our Understanding of The Theory and Practice of Social Media Marketing: Introduction To The Special Issue. Journal of Marketing Theory And Practice, 26(1-2), 1-3. doi: 10.1080/10696679.2018.1393277

Wirtz, J., \& Lovelock, C. (2016). Services marketing. New Jersey: World Scientific.

Yu, Q.; Asaad, Y.; Yen, D., \& Gupta, S. (2016). IMO and internal branding outcomes: an employee perspective in UK HE. Studies in Higher Education, 43(1), 37-56. doi: 10.1080/03075079.2016.1152467 
Zarantonello, L., \& Schmitt, B. (2010). Using the brand experience scale to profile consumers and predict consumer behaviour. Journal of Brand Management, 17(7), 532-540. doi: 10.1057/bm.2010.4

\section{Appendix:}

\section{FGC}

- I am satisfied with this university's social media communications conducted via Facebook.

- The level of this university's social media communications conducted via Facebook meets my expectations.

- This university's social media communications conducted via Facebook are very attractive.

- This university's social media communications conducted via Facebook perform well, when compared with the social media communications of other universities.

\section{UGC}

- I am satisfied with the content generated on Facebook by other users about this university.

- The level of the content generated on Facebook by other users about this university meets my expectations.

- The content generated on Facebook by other users about this university is very attractive.

- The content generated on Facebook by other users about this university performs well, when compared with other universities.

\section{Online Brand Experience}

- The layout of this university on Facebook page is appealing.

- This university's Facebook page is easy to navigate.

- Responses are always returned promptly when asking on this university's Facebook page.

- The information of this university are always up-to-date on its Facebook page.

- Accurate search results are always returned when browsing this university's Facebook page. 


\section{CBBE Dimensions}

\section{Social Image}

- I can expect outstanding teaching quality from this university.

- During the study period, I found that the quality of this university was less disposed to errors.

- This university seems to be a learning place without quality problems.

- I feel this university works very well.

\section{Performance}

- I feel this university suits my personality.

- I feel proud of my decision to enroll in this university.

- This university will be well appreciated by my friends.

- Based on the information on social networks, this university is suitable for my personality.

\section{Attachment}

- After experiencing this university, I was very pleased with my growth and knowledge.

- I have a positive feeling for this university.

- The time at this university helped me feel friendlier towards this university.

\section{Value}

- This university is well priced.

- Considering what I would pay for this university, I will get much more than money's worth.

- I consider this university to be inexpensive because of the benefits I receive.

\section{Trustworthiness}

- I consider this university and the people who stand behind this university to be very trustworthy.

- In regard to students' interests, this university seems to be very caring.

- I believe that this university does not take advantage of students. 


\title{
دور وسائل التواصل الاجتماعى على تجربة وأبعاد العلامة التجارية عبرالانترنت : من خلال تطبيقها فى مجال التعليم العالي
}

\author{
د. هببة حسن صـادق \\ ملخص البحث باللغة العربية
}

أدت المنافســة المتزايدة الموجودة بيين الجامعات وخاصــة الجامعات الخاصـــة والدولية في قطاع التعليم العالي إلى التركيزعلى بناء علامتها التجارية الخاصة للحصول على مكانة فريدة. لذلك، تركز هذه الدراسـة على العلامة التجارية من خلال وسـائل

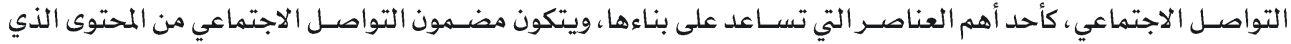

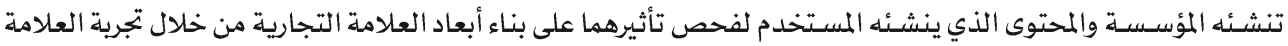
التجارية عبرا لإنترنت في قطاع التعليم العالي المصـري. تم توزيع الاسـتبيانات إلكترونيا لجمع البيانات. تم جمع البيانات من

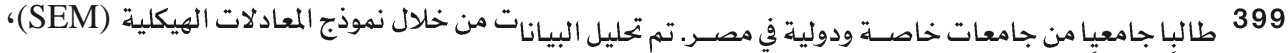

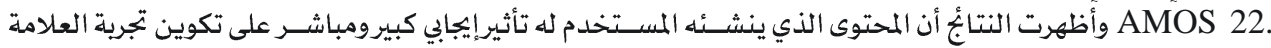

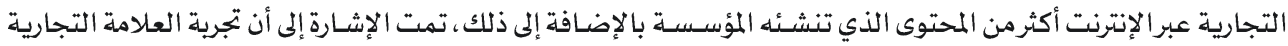

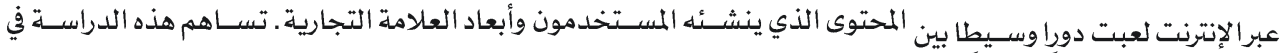

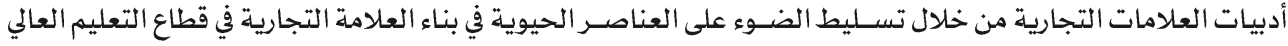

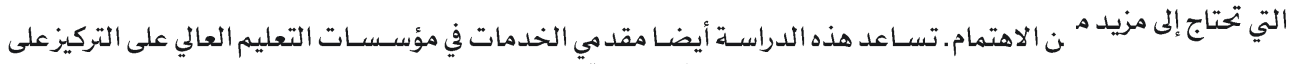

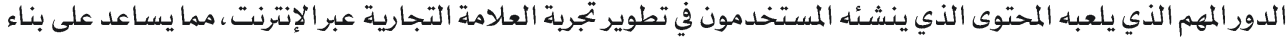

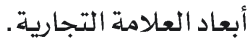

الكلمات الدالة : التواصل الاجتماعي، تجربة العلامة التجارية عبر الإنترنت، أبعاد العلامة التجارية ، قطاع التعليم العالي

\section{Suggested Citation according to APA Style}

Sadek, H. H. (2021). Role of Social Media Brand Communication on Online Brand Experience and Brand Equity Dimensions: Applying to the Higher Education Sector. Journal of Alexandria University for Administrative Sciences, Faculty of Commerce, Alexandria University 58(5), 103 - 137. 